\title{
MIGRAÇÃO PRÉ-EMPILHAMENTO ATRAVÉS DAS EQUAÇÕES DE ONDAS UNIDIRECIONAIS COM AMPLITUDE VERDADEIRA
}

\author{
Flor Alba Vivas Mejia \\ Orientador: Dr. Reynam da Cruz Pestana (UFBA) \\ 98 p. - Tese (Doutorado) - Defesa 01.08.2008
}

\begin{abstract}
RESUMO. A migração em profundidade baseada nas equações das ondas unidirecionais (OWWE - de suas iniciais em inglês) é utilizada com sucesso no imageamento de estruturas complexas, associadas com corpos de sal, com um custo computacional muito menor que a migração reversa no tempo (RTM - de suas iniciais em inglês). No entanto, pode-se mostrar de diferentes formas que as equações de ondas unidirecionais não são equivalentes à equação de onda acústica o que produz erros de fase e de amplitude nos campos de onda unidirecionais em relação aos campos de onda completa, embora o comportamento cinemático do campo de onda seja correto. Os erros de amplitude nos campos de onda unidirecionais estão relacionados ao fato que as equações de ondas unidirecionais não obedecem aos princípios de reciprocidade e conservação da energia, duas propriedades fundamentais satisfeitas pela equação acústica da onda. As informações dinâmicas do campo de onda, isto é, informações de fase e de amplitude são necessárias quando, além da posição do refletor, se está interessado em realizar estudos, tais como AVA (variação de amplitude versus ângulo) após a migração. Uma abordagem utilizada para melhorar o comportamento dinâmico das equações consiste em fazer modificações nos operadores OWWE através da introdução de um termo extra que tem dependência explícita da derivada vertical da velocidade $v_{z}(x, y, z)$, assim como a modificação do operador Laplaciano transversal, que inclui termos com dependência explíita das derivadas laterais da velocidade $\left(v_{x}(x, y, z), v_{y}(x, y, z)\right)$, passando esse novo conjunto de equações a ser chamado de equações de ondas unidirecionais com amplitude verdadeira (TA-OWWE). Num campo de velocidades que varia suavemente com a profundidade, $v=v(z)$, as equações de ondas unidirecionais com amplitude verdadeira proporcionam as mesmas amplitudes que a equação da onda acústica, como pode ser demonstrado através da aproximação WKBJ. Os termos de correção das amplitudes podem ser aplicados no domínio número de onda global. Nesta tese é apresentada uma análise das equações de ondas unidirecionais com amplitude verdadeira, uma descrição em detalhe dos novos termos nos operadores que garantem sua equivalência, numa aproximação assintótica, com a equação de onda completa. Em seguida, descreve-se como os algoritmos de migração convencionais no domínio misto, tais como deslocamento de fase mais interpolação (PSPI), deslocamento de fase em duas etapas (SS) e Fourier diferenças finitas (FFD), devem ser ajustados para incluir correções de fase e amplitude, de acordo com as novas equações unidirecionais com amplitude verdadeira para meios completamente heterogêneos, onde 0 campo de velocidades tem variação lateral, além de vertical. Também experimentos numéricos em dados sintéticos de tiro comum 2D são apresentados, bem como as comparações das amplitudes recuperadas sobre os refletores, usando-se os esquemas de migração convencional e os esquemas com correções de amplitude propostos.
\end{abstract}

ABSTRACT. Depth migration based on one-way wave equations (OWWE) has been used as a powerful tool for imaging complex structures, associated with salt bodies, with less computational cost than reverse time migration. Unfortunately, the OWWE are not equivalent to the acoustic wave equation whose behavior they are designed to mimic, leading to a migrated wavefield that lacks correct amplitude and phase behavior, even though it is kinematically correct. The amplitude errors in one-way wave equations are related to the fact that one way wave equations fail to conserve energy and reciprocity, two widely recognized fundamental properties of the two-way wave equation. When dynamic information after migration is required, such as amplitudes to AVA studies, or more correct amplitudes along the reflectors in the zero offset image are needed, it is necessary modify the OWWE to explicitly include derivatives of the medium velocity through both, the introduction of an extra term with explicit dependence of vertical velocity variation $v_{z}(x, y, z)$, and the modification of the transverse Laplacian operator to include terms with explicit dependence of transverse velocity variations $\left(v_{x}(x, y, z), v_{y}(x, y, z)\right)$. The resulting new equations are called true-amplitude one-way wave equations (TA-OWWE). In a vertically smoothly varying $v(z)$ medium, the true-amplitude one-way wave equations give the same amplitude as the acoustic wave equation up to the first order in the WKBJ approximation. The necessary amplitude correction can be applied in the global wavenumber domain. In this thesis, the true-amplitude one-way wave equations (TA-OWWE) are analyzed in detail, moreover, it is described how the conventional migration algorithms in the mixed domain, such as phase shift plus interpolation (PSPI), split-step (SS), and Fourier finite-difference (FFD), can be adjusted to make corrections in the amplitudes in agreement with the true-amplitude one-way wave equations for laterally varying media. 2D numerical experiments with common-shot synthetic data are presented and the amplitudes recovered along the reflectors with conventional and true-amplitude one-way wave equations migration are compared. 